\title{
Treatment of people exposed to, suspected of being infected, or infected with SARS CoV-2 virus - Evolution of legal regulations
}

\author{
Postępowanie wobec osób podejrzanych o zakażenie lub zakażonych \\ wirusem SARS-CoV-2. Ewolucja przepisów prawa
}

\author{
Anna Augustynowicz ${ }^{1, \mathrm{~A}-\mathrm{D} \oplus}$, Michał Waszkiewicz ${ }^{1, \mathrm{E}-\mathrm{F} \oplus}$, Aleksandra Czerw $^{2, \mathrm{E}-\mathrm{F} \oplus}$ \\ ${ }^{1}$ Centre of Postgraduate Medical Education, Warsaw, Poland \\ ${ }^{2}$ National Institute of Public Health - National Institute of Hygiene, Warsaw, Poland \\ A - Research concept and design, B - Collection and/or assembly of data, C - Data analysis and interpretation, \\ $D$ - Writing the article, E - Critical revision of the article, F - Final approval of article
}

Augustynowicz A, Waszkiewicz M, Czerw A. Treatment of people exposed to, suspected of being infected or infected with SARS CoV-2 virus. Evolution of legal regulations. Med Og Nauk Zdr. 2021; 27(1): 1-6. doi: 10.26444/monz/131926

\section{Abstract}

Introduction. The state of epidemic, caused by the SARS CoV-2 virus, introduced in Poland on 20 March 2020, significantly affected the situation of entities conducting medical activities, patients and medical staff. Therefore, the activity of the legislator introducing legal provisions regulating the functioning of the healthcare system under epidemic conditions is not surprising. One of the directions of the changes introduced was to regulate specific principles of conduct in the event of exposure to SARS CoV-2 virus infection, suspicion or diagnosis of infection with this virus, as well as suspicion or diagnosis of the disease caused by it (COVID 19). Objective. The aim of the study is to present selected regulations regarding the procedure in the case of exposure to SARS CoV-2 virus infection, suspected or diagnosed infection with this virus, as well as suspected or diagnosed disease caused by it (COVID 19).

Materials and method. Acts of universally binding law on preventing and combatting infections and infectious diseases in Poland and Acts of universally binding law adopted in connection with the spread of SARS CoV-2 virus were used. The method of analysing legal Acts and references was used. Conclusions. In the case of airborne diseases in people, limiting the spread of an infectious agent is inseparably connected with the need to limit contact of infected people or people suspected of contact with an infectious agent with healthy people. This, in turn, would not be possible without mechanisms guaranteeing effective and sufficient isolation of these people. Due to the nature of these activities, they must be associated with a limitation of basic personal rights, such as freedom of movement or voluntary submission to diagnostic or therapeutic procedures.

\section{Key words}

SARS CoV-2 virus, COVID 19, quarantine, hospitalization, isolation

\section{Streszczenie}

Wprowadzenie i cel pracy. Obowiązujący w Polsce od 20 marca 2020 r. stan epidemii związany z zakażeniami wirusem SARS-CoV-2 znacząco wpłynął na sytuację podmiotów wykonujących działalność leczniczą, pacjentów i personelu medycznego. Nie dziwi więc, iż ustawodawca wprowadził przepisy prawa regulujące funkcjonowanie systemu ochrony zdrowia w warunkach epidemii. Celem pracy jest przedstawienie wybranych regulacji dotyczących postępowania w razie narażenia na zakażenie wirusem SARS-CoV-2, podejrzenia lub rozpoznania zakażenia tym wirusem, a także podejrzenia lub rozpoznania choroby nim wywołanej (COVID-19).

Rozwiązania prawne. Od 28 lutego 2020 r. zakażenie wirusem SARS-CoV-2 zostało objęte przepisami ustawy o zapobieganiu i zwalczaniu zakażeń i chorób zakaźnych u ludzi. Pozwoliło to na zastosowanie określonych w powyższej ustawie instrumentów prawnych wobec osób podejrzanych o zakażenie i zakażonych tym wirusem. W przypadku zakażenia SARS-CoV-2 ustawodawca przewidział obowiązek kwarantanny, nadzoru epidemiologicznego, hospitalizacji, izolacji lub izolacji w domu.

Podsumowanie. W przypadku chorób przenoszonych drogą powietrzną u ludzi ograniczenie rozprzestrzeniania się czynnika zakaźnego nierozerwalnie wiąże się z koniecznością ograniczenia kontaktu osób zakażonych lub podejrzanych o kontakt z czynnikiem zakaźnym z osobami zdrowymi. To z kolei nie byłoby możliwe bez mechanizmów gwarantujących skuteczną i wystarczającą izolację tych osób. Ze względu na charakter tych czynności muszą one wiązać się z ograniczeniem podstawowych dóbr osobistych, takich jak swoboda przemieszczania się czy dobrowolność poddawania się zabiegom diagnostycznym lub terapeutycznym.

\section{Słowa kluczowe}

hospitalizacja, izolacja, kwarantanna, wirus SARS-CoV-2, COVID-19 


\section{INTRODUCTION}

The Polish health care system and the medical law system were not fully prepared for the unexpected epidemic situation caused by the SARS CoV-2 virus. Due to the dynamic spread of infections by this virus, the Polish legislator was forced to react on an ongoing basis to an unexpected and changing situation. To protect public health and ensure the safety of citizens, as well as guarantee medical care to persons suspected of being infected or infected with the SARS CoV-2 virus, a number of legal regulations were introduced. Regulations which, as a result of changes in the epidemiological situation, have been subject to numerous amendments.

The basic legal Act regulating the principles and procedure for preventing and combating infections and the spread of infectious diseases in humans in Poland is the Act of 5 December 2008 on preventing and combating infections and infectious diseases in humans. It is worth noting that the provisions of the Act apply only to infections and infectious diseases, the list of which is set out in the Annex to this Act. However, considering the date of adopting the abovementioned Act, the scope of its activities did not include SARS CoV-2 infection. This situation has changed under the Regulation of the Minister of Health of 27 February 2020 on SARS CoV-2 [1] infection. Starting from 28 February 2020, SARS CoV-2 infection will be subject to the provisions of the Act on preventing and combating infections and infectious diseases in humans. In addition, on 2 March 2020, an Act was adopted on specific solutions related to the prevention, counteraction and eradication of COVID-19, other infectious diseases, and the crisis situations caused by them [2] $]^{1}$. It complements the basic regulations contained in the Act on preventing and combating infections and infectious diseases in humans.

Pursuant to the provisions of the Act on preventing and combating infections and infectious diseases in humans, the Minister of Health announced the state of epidemiological threat in connection with SARS-CoV-2 infection [3] in Poland, starting from 14 March 2020. Subsequently, from 20 March 20, the state of epidemic [4] was announced. Along with the announcement of the state of epidemiological threat and then the state of epidemic, a number of restrictions and prohibitions ${ }^{2}$ were introduced. The state of epidemic has also significantly affected the situation of healthcare providers, patients and medical staff. Therefore, the activity of the legislator introducing legal provisions regulating the functioning of the healthcare system under epidemic

1. From the date of entry into force (i.e. 8 March 2020) until the end of October, the provisions of this Act were amended 12 times. Another amending Act, i.e. the Act amending certain Acts in connection with counteracting crises related to the occurrence of COVID-19, was passed by the Sejm (Parliament) of the Republic of Poland on 28 October this year (2020), signed by the President of the Republic of Poland on 3 November this year. As of 15 November, the Act was not published in the Journal of Laws.

2. The restrictions introduced include restrictions on the manner of movement (e.g. suspension of passenger movement in rail transport with the crossing of the border of the Republic of Poland), restrictions or prohibitions on trade and use of specific items (e.g. prohibition of respirators and cardiac monitors, protective goggles, surgical masks, goggles and surgical masks, latex gloves being exported or sold outside the territory of the Republic of Poland), restrictions on the functioning of specific institutions or workplaces (e.g. schools, kindergartens, nurseries, universities, restrictions on the operation of shopping malls), a ban on organizing shows and other gatherings. conditions is not surprising. One of the directions of the changes introduced was to regulate specific principles of conduct in the event of exposure to infection with SARS $\mathrm{CoV}-2$ virus, suspicion or diagnosis of infection with this virus, as well as suspicion or diagnosis of the disease caused by it (COVID 19).

\section{OBJECTIVE}

The aim of the study is to present regulations regarding the procedure in the case of exposure to SARS CoV-2 virus infection, suspected or diagnosed infection with this virus, as well as suspected or diagnosed disease caused by it (COVID 19).

\section{MATERIALS AND METHOD}

Acts of universally binding law on preventing and combating infections and infectious diseases in Poland and Acts of universally binding law adopted in connection with the spread of SARS CoV-2 virus were used. The method of analysing legal acts and references was used.

Detailed legal solutions. From 28 February 2020, SARS$\mathrm{CoV}-2$ virus infection was covered by the provisions of the Act on preventing and combating infections and infectious diseases in humans. This allowed for the use of legal instruments specified in the above Act on persons suspected of being infected and infected with this virus. Instruments which, due to the social nature of epidemiological threats and the specificity of counteracting these threats, often significantly limit the autonomy of individuals. In this regard, the dilemma between the values related to the protection of public health and the protection of fundamental rights of individuals, in principle, is resolved in favour of the former.

The Act on preventing and combating infections and infectious diseases in humans obliges persons residing in the territory of the Republic of Poland who are infected or suffering from an infectious disease or suspected of having an infection or infectious disease, or who have been in contact with a source of a biological pathogen, to undergo protective procedures, protective vaccinations, post-exposure prophylactic use of medications, sanitary and epidemiological tests, epidemiological supervision, quarantine, treatment, hospitalization, isolation and isolation at home (Art. 5 sec. 1 of the Act).

As a rule, these obligations are imposed by way of an administrative decision by the poviat (county) or State border sanitary inspector. These decisions are immediately enforceable. If these decisions are issued in the event of a suspected infection or a particularly dangerous and highly infectious disease that poses a direct threat to the health or life of others, they may be communicated in any way possible, including orally, to ensure that the decision reaches the addressees. If the decision is communicated in a manner other than in writing, it is then served in writing after the reasons preventing delivery in this way have ceased to exist. These decisions do not require justification. Although the Act on preventing and combating infections and infectious diseases in humans does not directly determine means of appeal against the above decisions of the competent 
sanitary inspector, nevertheless, in accordance with the general principles regarding administrative proceedings, an appeal to a higher authority (in this case a voivodship [provincial] sanitary inspector), and then a complaint to the administrative court will be such a mean [5].

Exceptionally, but only in the case of suspicion or diagnosis with a particularly dangerous and highly infectious disease, the physician decides on the implementation of some of the above-mentioned obligations. In this situation, the physician subjects a person suspected of being sick, sick or exposed to infection to hospitalization, isolation, and quarantine, even if the person does not agree to the use of restrictions.

Pursuant to the provisions of the regulation of 6 April 2020 on infectious diseases resulting in the obligation of hospitalization, isolation or isolation at home and the obligation of quarantine or epidemiological surveillance, in the event of exposure to infection or infection with SARS CoV-2, the obligation of quarantine, epidemiological surveillance, obligatory hospitalization, isolation or isolation at home arises $[6]^{3,4}$.

The obligation of quarantine or epidemiological supervision arises when exposed to the disease caused by the SARSCoV-2 virus (COVID-19) or in contact with the source of biological pathogens causing it. Quarantine means isolation of a healthy person who has been exposed to infection to prevent the spread of particularly dangerous and highly infectious diseases. Initially, the provisions of the abovementioned regulation indicated that the quarantine lasts 14 days from the day following the last day of exposure or contact, respectively. According to the regulations in force as of 15 November this year (2020), the period of compulsory quarantine due to exposure to SARS CoV 2 infection in people who did not develop symptoms of COVID 19, or came into contact with the source of the infection ends after 10 days, counting from the day following the last day of exposure or contact, respectively. In the case of a person who lives in or runs a common household with a person infected with SARS CoV 2 and who has been subjected to isolation at home for this reason, the period of compulsory quarantine ends 7 days after the end of isolation. In the case of a person referred for laboratory diagnostics for the SARS $\mathrm{CoV} 2$ virus, the period of compulsory quarantine ends when the SARS CoV 2 diagnostic test result is negative, but not later than 10 days from the day following the referral for the diagnostic test for SARS CoV 2. A person obliged to undergo quarantine may not leave the place of its execution. As a rule, quarantine is carried out at home. Nevertheless, according to the Act, in the event of the necessity of quarantine, the voivode (local governor) mensures the conditions of isolation or quarantine by providing appropriate premises, equipment and sending people with appropriate qualifications to work. It is obvious that a person undergoing quarantine may experience symptoms of SARS CoV-2 disease due to previous exposure. In this case, other measures provided for by law will

3. The provisions of this regulation were amended six times. By amending the regulations of 17 June, 29 June 29, 1 September, 8 September, 8 October and 3 November (the amending regulations are published respectively in the Journal of Laws of 2020, items 1054, $1164,1506,1550,1748,1942)$, the laws on the duration of quarantine, isolation or isolation at home were modified.

4. Isolation at home is a new form of limiting the autonomy of individuals introduced in connection with specific solutions related to the prevention, counteraction, and eradication of COVID-19. be applied to the quarantined person, namely, compulsory hospitalization, isolation, or isolation at home.

Another legal instrument applicable in the context of combating SARS CoV-2 infections is the obligation of hospitalization. One of the first decisions of the authorities of the Republic of Poland in response to the epidemic situation, made in spring 2020, was to transform a dozen or so hospitals throughout the country into infectious diseases hospitals, which would only deal with patients suspected of being infected and infected with the SARS CoV-2 virus (so-called single-name hospitals). The legal basis for transforming some hospitals into the so-called single-name hospitals was the afore-mentioned Act on special solutions related to the prevention, counteraction and eradication of COVID-19, other infectious diseases and crisis situations caused by them. Art. 10 and 11 of this Act provided for the possibility of issuing instructions, by way of an administrative decision, by a voivode (local governor), the Minister of Health and the Prime Minister, to specific entities. These instructions may have concerned, among others, transformation into singlename hospitals for the purpose of providing health services in relation to counteracting COVID 19. These hospitals were to treat patients infected with the SARS CoV-2 virus who were also burdened with other diseases. Such facilities were required to be equipped with, among others, operating rooms and treatment room, as well as delivery rooms for pregnant women infected with the SARS CoV-2 virus. At least 10 percent of ventilator beds were to operate in each hospital. A list of single-name hospitals was published on 13 March 2020. These hospitals were to receive patients infected with the SARS-CoV-2 virus as of 16 March this year (2020). Finally, 21 facilities were transformed into single-name hospitals. The hospitals were situated in the following voivodeships (Provinces) Silesia, Warmian-Masuria, Greater Poland - two hospitals, Pomerania - three hospitals, and in Lower Silesia, Kuyavian-Pomerania, Lublin, Lubusz, Lodz, Lesser Poland, Masovia, Opole, Podkarpackie, Podlasie, Świętokrzyskie, and West Pomerania - one hospital in each voivodeship (Province). In addition, in each voivodship (Province) at least one additional infectious diseases hospital was to be operating to treat patients infected with the SARS CoV-2 virus. In addition, infectious diseases departments operating in hospitals were also to treat patients - there are currently 79 such departments. Along with the stabilization of the epidemiological situation in Poland, since June this year (2020) the function of normal work in single-name hospitals has been gradually restored. Obviously, starting with the voivodeships (Provinces) with the lowest number of new infections and the least occupied beds in single-name hospitals.

The deterioration of the epidemiological situation resulted in further changes in the organization of care for patients suspected of being infected or infected with the SARS CoV-2 virus. On the orders of the voivode (local governor) or the Minister of Health, issued respectively pursuant to Art. 10 or 11 of the Act on special solutions related to preventing, counteracting and combating COVID-19, other infectious disease, and the crises caused by them, level 1, 2 and 3 hospitals were established. Level 1 hospitals are to provide beds for patients suspected of being infected with SARS$\mathrm{CoV}-2$. Level 2 hospitals are required to treat patients infected with the SARS-CoV-2 virus who require hospitalization. In contrast, level 3 hospitals are required to treat patients with diseases other than COVID-19 requiring hospitalization 
due to infection with the SARS-CoV-2 virus [7]. In addition, from among hospitals caring for patients infected with the SARS CoV-2 virus, so-called coordinating hospitals have been appointed. Moreover, pursuant to the order of the Prime Minister issued pursuant to Art. $11 \mathrm{~h} \mathrm{sec.} 3$ of the Act on special solutions related to preventing, counteracting and combating COVID-19, other infectious diseases and the crises caused by them, so-called temporary hospitals have been established ${ }^{5}$. They function as organizational units of medical entities providing health services outside the headquarters of a given entity.

Returning to the discussion about the issue of compulsory hospitalization, it should be pointed out thatthist involves persons who have been infected with SARS-CoV-2 virus or diagnosed with this disease caused by it (COVID-19), or suspected of being infected or sick, unless they were referred by a physician for treatment or laboratory diagnostics for SARS-CoV-2 virus as part of compulsory isolation or isolation at home [6] ${ }^{6}$. If the physician makes a decision about compulsory hospitalization, he/she refers the patient to a 'specific hospital'. The question then arises: what should be understood by the phrase 'refers to a specific hospital'? Answering this question requires, first of all, an indication of who, according to Art. 7 of the Act on specific solutions related to the prevention, counteraction and eradication of

5. Art. $11 \mathrm{~h}$ was added by the Act of 7 October 2020 on amending certain Acts to counteract the socio-economic effects of COVID 19 (Journal of Laws of 2020, item 1747). Pursuant to this provision, during the period of the epidemic threat or epidemic state, the Prime Minister may, on his own initiative, issue orders binding on specific entities. By issuing an order to an entrepreneur, the Prime Minister may designate an authority responsible for concluding a given contract.

6 . The obligation of hospitalization related to combating the SARS CoV-2 virus is a legal instrument that has been changing extremely dynamically. Initially, i.e. from $8 \mathrm{March}$, sick people or people suspected of being infected with biological pathogens causing severe acute respiratory distress syndrome (SARS), or other organ failure, including SARS-CoV-2 coronavirus infection, were subjected to compulsory hospitalization (Regulation of the Minister of Health of 7 March 2020 on the list of diseases that give rise to the obligation of hospitalization, Journal of Laws of 2020, item 375). This regulation was only valid for five days. Starting from 12 March 2020, this obligation was lifted for persons suspected of being infected with SARS-CoV-2 virus (Regulation of the Minister of Health of 11 March 2020, amending the Regulation on the list of diseases causing the obligation of hospitalization, Journal of Laws of 2020, item 409). The obligation of hospitalization involved persons with an infection or infectious disease caused by SARS-CoV-2 virus. Another change came into force on 15 March 2020 which involved the obligation of hospitalization of persons who were diagnosed with the disease caused by the SARS-CoV-2 coronavirus (COVID-19), unless they were referred by a physician for treatment in isolation at home (Regulation of the Minister of Health of 14 March 2020, amending the regulation on the list of diseases causing the obligation of hospitalization, Journal of Laws of 2010, item 438). On 23 March, another change to the regulations was introduced, this time involving the obligation of hospitalization of persons who were diagnosed with the disease caused by the SARS-CoV-2 virus (COVID-19), or suspected of being sick if they were not referred by a physician for treatment or laboratory diagnosis for SARS-CoV-2 virus as part of isolation outside the hospital, including isolation at home (Regulation of the Minister of Health of 23 March 2020, amending the regulation on the list of diseases causing the obligation of hospitalization, Journal of Laws of 2020, item 510). Currently, the issue of compulsory hospitalization is governed by the provisions of the Regulation of 6 April 62020 on infectious diseases resulting in the obligation of hospitalization, isolation or isolation at home, and the obligation of quarantine or epidemiological supervision (Regulation of the Minister of Health of 6 April 2020 on infectious diseases, causing the obligation of hospitalization, isolation or isolation at home and the obligation of quarantine or epidemiological supervision, Journal of Laws of 2020, item 607).
COVID-19, other infectious diseases, and crisis situations caused by them [2], the healthcare services provided in connection with counteracting COVID-19 are provided by entities conducting medical activity (i.e. hospitals, outpatient clinics) or physicians and dentists providing services via an ICT system, entered in the list developed by the locally competent director of the department of the voivodeship (provincial) National Health Fund in consultation with the voivode (local governor). The list includes entities performing medical activity as well as physicians and dentists, taking into account the needs arising from securing the availability of healthcare services in the voivodship (Province), as well as the organizational structure of these entities, the type of medical activity performed, as well as personnel and equipment resources. The list of these entities is published in the voivodship official journal of the Province through an announcement by the local governor, and in the Public Information Bulletin of the National Health Fund.

Health care services provided in connection with counteracting COVID-19, provided by the above-mentioned entities, are financed by the National Health Fund from the funds of the COVID-19 Counteracting Fund and from the part of the State budget managed by the Minister of Health, based on reports and bills submitted to the locally competent director of the voivod (provincial) branch of the National Health Fund. Health care services are financed in the form of a flat-rate fee for maintaining readiness to provide these services and the price corresponding to the number and type of health care services provided in the assumed accounting period. Taking into account the above considerations, a physician may refer a patient to a hospital entered in the list developed by the locally competent director of the voivodship (provincial) branch of the National Health Fund in consultation with the voivode (local governor). Currently, these are level 1, 2 or 3 hospitals, as well as infectious diseases hospitals and hospitals withan infectious diseases department.

If a physician has not applied compulsory hospitalization to a person who has been diagnosed with an infection caused by SARS-CoV-2 virus or a disease caused by SARS-CoV-2 virus (COVID-19, or suspected of an infection or disease, the physician should refer that person to mandatory isolation or isolation at home. According to the statutory definition, isolation means the isolation of a person or group of persons suffering from an infectious disease or suspected of an infectious disease, in order to limit the infection. Isolation at home is a new instrument set out in the Act. It means isolation of a person with an infectious disease who does not require absolute hospitalization for medical reasons at his/her place of residence or stay. Additionally, in the case of home isolation, the legislator introduced an additional condition. This isolation aims to prevent the spread of particularly dangerous and highly infectious diseases.

Home isolation, in the case of a symptomatic patient, ends after 3 days without fever and without symptoms of respiratory infection, but not earlier than 13 days from the day of the onset of symptoms, unless the primary care physician who provided teleconsultation or advice at home, not earlier than on the eighth day of this isolation, will extend its duration. In the case of an asymptomatic patient, home isolation ends 10 days from the date of the first positive SARS CoV 2 diagnostic test, unless the physician extends its duration. 
A hospital physician, primary care physician or a State sanitary inspector may refer a person diagnosed with the disease or suspected of COVID 19 to an isolation facility. Persons referred to above, from whom biological material was collected to conduct a test for the presence of the SARS-CoV-2 virus, are eligible for care in an isolation facility. Persons referred to an isolation facility with a positive test result must stay there until the symptoms resolve, and the control test result is negative and another SARS-CoV-2 virus control test result is negative, or a decision is made to transfer that person to an infectious diseases hospital due to a deterioration in their health. Additionally, those hospitalized for COVID-19, not requiring hospital treatment, stay in isolation facilities until they obtain a negative control test result and a negative control re-test result for the presence of SARS-CoV-2 virus. An isolated person with clinical symptoms may be discharged from the isolation facility after three days without fever and without symptoms of respiratory infection, but not earlier than 13 days from the day of the onset of symptoms. Persons without clinical symptoms can be discharged from the isolation facility 10 days after the first positive result of the diagnostic test for SARS CoV 2.

Care in isolation facilities involves providing a place to stay, and in the case of people who have been diagnosed with a disease caused by the SARS-CoV-2 virus or suspected of having the disease, it also involves medical care. Health care in isolation facilities is provided by a medical entity that performs medical activities, such as hospital treatment. As part of care provided in isolation facilities, nursing visits, medical advice, collection of biological material for diagnostic tests for the presence of SARS-CoV-2 virus, and transport in the event of the need to transport an isolated person to hospital due to a deterioration of his/her health, are provided. Detailed standards of care in isolation facilities in connection with counteracting SARS-CoV-2 virus infection are set out in the Regulation of the Minister of Health of 26 March 2020 on the organizational standard of care in isolation facilities $[8]^{7}$. Costs for the stay of a patient and costs of medical care in isolation facilities are financed from public funds.

Isolation facilities are established in facilities indicated by voivodes (local governors). They may include hotels, hostels, sanatoriums, dormitories, etc., provided they meet the requirements set out in the regulation on the organizational standard of care in isolation facilities. In principle, they should be located near hospitals providing services to patients with COVID 19. Medical staff at these hospitals will look after isolated patients [9].

A physician who refers a patient for mandatory hospitalization or mandatory isolation is also required to immediately provide information about the referral to the State poviat (Regional) sanitary inspector or State border sanitary inspector competent for the place of stay of the person suspected of being infected or sick. Moreover, he/ she is obliged to instruct the sick person or the person with legal custody of a sick minor or helpless person, or the actual caregiver, about the obligation of hospitalization or isolation at home, and to note this fact in the patient's medical records and order sanitary transport to the indicated hospital or place of isolation or isolation at home in the case of a patient who

7. This regulation was amended six times by amending regulations of 3 April, 27 April, 12 May, 1 September, 8 October and 27 October (the amending regulations are published respectively in the Journal of Laws of 2020, items 597, 761, 847, 1507, 1750, 1890). is unable to move independently, or whose health justifies it, or provides the patient with information about the need not to travel by means of public transport.

A question arises here whether consent (of the subject) for compulsory hospitalization or isolation is required. In Polish literature, a view is presented that even with regard to persons subject to the obligations arising from the Act on preventing and combating infections and infectious diseases in humans, their consent for specific actions should be obtained $[10,11]$. Consent should be expressed by the patient him/herself, if he/she is of legal age. In the case of a minor patient, consent is given by his/her legal representative [12]. Consent is particularly significant in the case of compulsory hospitalization and isolation in isolation facilities. In the case of isolation at home, instructing the patient about the obligations arising from isolation is most important.

Doubts also concern the physician's rights when a person referred for obligatory hospitalization or isolation evades these obligations. In medical practice, it may happen that a patient does not comply with the imposed obligations and is not convinced by arguments related to a possible threat to his/her health or life, or health or life of others. In such a situation, can the physician use means of direct coercion? The Act on preventing and combating infections and infectious diseases in humans allows, under certain conditions, for the use of direct coercion. First of all, direct coercion can be applied only towards a person who does not fulfil the vaccination obligation, sanitary and epidemiological tests, sanitary procedures, quarantine, isolation or mandatory hospitalization. Secondly, the use of direct coercion is possible in relation to patients or persons suspected of developing a particularly dangerous and highly infectious disease. Thirdly, this disease poses a direct threat to the health or life of others.

Pursuant to the Act, a 'particularly dangerous and highly infectious disease' is an infectious disease which is easily spread, has a high mortality rate, causes particular threats to public heal, and requires special methods of eradication. For example, the legislator mentions cholera, plague, smallpox and viral haemorrhagic fevers. Epidemiological data indicates that these are diseases where the mortality rate ranges from $30 \%-50 \%$. However, although in the statutory definition, the disease caused by the SARS CoV-2 virus is not mentioned among the highly dangerous and particularly infectious diseases, this does not mean that this disease is not of such a nature because the calculation made by the legislator is not enumerative. Certainly, the intention of the Polish legislator was to recognize the disease caused by the SARS CoV-2 virus as highly dangerous and particularly infectious. Regardless, it is worth emphasizing that it is not the intention of the legislator that decides whether the disease caused by the SARS CoV-2 virus is highly dangerous and particularly infectious, but the fulfilment of conditions set out in the definition of this disease. In the case of the SARS$\mathrm{CoV}-2$ virus, this is undoubtedly an infectious disease that is easily spread and requires specific methods of eradication. A doubt concerns high mortality. However, in March 2020, when the amendments to the Act on preventing and combating infections and infectious diseases in humans were introduced, the legislator adopted this assumption.

The person authorized to make a decision on the use of direct coercion is the physician who determines its type and personally supervises its execution by persons practicing 
medical professions. The physician may ask the Police, Border Guards or the Military Police for assistance in applying direct coercion. Assistance is provided if the officers or soldiers are equipped with means of protection against infectious diseases by the physician. Prior to the use of direct coercion, the person towards whom it is to be applied must be informed of this fact, and this fact is recorded in their medical records. In many cases, prior information of the patient about the possibility of using direct coercion, explaining the purpose and reason for its use to the patient, may facilitate his/her consent to the proposed procedure. At the same time, the Act specifies a catalogue of direct coercion measures, i.e. holding, immobilizing or compulsory drug administration.

If a patient being isolated or hospitalized leaves the hospital or isolation facility illicitly, medical personnel shall immediately inform by phone the State poviat (County) sanitary inspector competent for the patient's place of residence. In such cases, coercion allowing for the enforcement of imposed obligations remains the responsibility of theSstate poviat (county) sanitary inspector. The competent sanitary inspector may, based on the provisions of the Act on enforcement proceedings in administration, impose a socalled fine for the purpose of coercion. If a one-time fine is not effective, it may be re-imposed in the same or a higher amount. Each fine imposed may not exceed PLN 10,000, while fines imposed repeatedly may not exceed PLN 50,000 in total. In the event of non-compliance with the obligation of quarantine or breach of its rules, the State poviat (county) sanitary inspector or State border sanitary inspector imposes, pursuant to the Act on the prevention and combating of infectious diseases and infections in humans, a fine from PLN 5,000 up to PLN 30,000 by way of an administrative decision.

The sanitary inspector may also decide to apply a measure of direct coercion. Direct coercion involves bringing about the execution of an obligation by expressing the threat of applying or applying directly effective measures, including physical force, to eliminate resistance of the obligated person or persons who prevent execution of the obligations. The Act on enforcement proceedings in administration does not explicitly mention direct coercion measures. As a rule, in the case discussed here, it will involve direct influence on the person, e.g. bringing the person to the location of compulsory quarantine, hospitalization or isolation. In the case of use of direct coercion, assistance from the Police, Border Guards, Internal Security Agency or Foreign Intelligence Agency is possible.

\section{CONCLUSIONS}

As a rule, each of the presented institutions and legal solutions serves the same goal, which is to reduce the possibility of spreading the infectious agent. In the case of airborne diseases transmitted by humans, achieving this effect requires mechanisms, including legal mechanisms, that effectively limit the contact of infected people or people suspected of contact with an infectious agen, with healthy individuals. Due to the isolation nature of these activities, they must be connected to the limitation of basic personal rights, such as, for example, freedom of movement, and the voluntary nature of undergoing diagnostic or therapeutic procedures. This causes exceptional difficulties in their design, implementation and effective application, without being exposed to an accusation of inadequacy of solutions in relation to the purpose for which they are introduced into the legal system. For this reason, a particular duty of the legislator is to adequately adapt such specific legal institutions to the current epidemiological situation and the progress of medical knowledge based on scientific evidence.

Due to the multiplicity of factors influencing the epidemiological rates of SARS-CoV-2 infections and COVID-19 cases, the actual assessment of the effectiveness and adequacy of the legal tools used, described by the authors, as the sole factors limiting the spread of the virus, on the one hand, and guaranteeing improvement of care provided to those in need, on the other, seems extremely difficult. However, it should be emphasized that such an analysis was not the authors' objective.

In the authors' opinion, activities in the legislative and legal sphere, combined with an effective information campaign and enforcement of applicable regulations, constitute an important supplement to the basic activities of the State in counteracting the effects of the COVID-19 epidemic.

\section{REFERENCES}

1. Regulation of the Minister of Health of February 27, 2020 on SARS CoV-2 coronavirus infection (Journal of Laws of 2020, item 325).

2. Act of March 2, 2020 on special solutions related to the prevention, counteraction and eradication of COVID-19, other infectious diseases and crisis situations caused by them (Journal of Laws of 2020, item 374 , as amended).

3. Regulation of the Minister of Health of March 13, 2020 regarding the announcement of an epidemic emergency in the territory of the Republic of Poland (Journal of Laws of 2020, item 433).

4. Regulation of the Minister of Health of March 20, 2020 regarding the announcement of the state of epidemic in the territory of the Republic of Poland (Journal of Laws of 2020, item 491).

5. Paszkowska M. Instrumenty przymusu stosowane wobec osób podejrzanych oraz chorych na choroby zakaźne (w tym COVID 19) https://www.wolterskluwer.com/pl-pl (dostęp 2020.09.22).

6. Ordinance of the Minister of Health of April 6, 2020 on infectious diseases resulting in the obligation of hospitalization, isolation or isolation at home and the obligation of quarantine or epidemiological supervision (Journal of Laws of 2020, item 607).

7. Regulation of the Minister of Health of 8 October 2020 on the organizational standard of health care for a patient suspected of being infected or infected with SARS-CoV-2 virus (Journal of Laws of 2020, item 1749).

8. Regulation of the Minister of Health of March 26, 2020 on the organizational standard of care in isolation facilities (Journal of Laws of 2020 , item 539 , as amended).

9. Kwiatkowska M. Zasady sprawowania opieki w izolatoriach https:// www.wolterskluwer.com/pl-pl (dostęp 2020.09.22).

10.Zajdel J. Prawo w medycynie. Łódź Progress, 2006.

11. Augustynowicz A, Wrześniewska-Wal I. Ograniczenie autonomii pacjenta w diagnozowaniu i leczeniu gruźlicy. Pneumonologia i Alergologia Polska. 2013; 81: 130-136.

12. Dukiet-Nagórska T. Autonomia pacjenta a polskie prawo karne. Warszawa Wolters Kluwer Polska, 2008. 